\title{
EFFECT OF BIOSYNTHESIZED SILVER NANOPARTICLES ON Fusarium oxysporum FUNGUS THE CAUSE OF SEED ROT DISEASE OF FABA BEAN, TOMATO AND BARLEY Rabab M. Elamawi ${ }^{1^{*}}$ and Raida E. Al-Harbi ${ }^{2}$ \\ ${ }^{1}$ Rice Pathology Department, Plant Pathology Research Institute, BP 33717 Agricultural Research Center, Sakha, Egypt. *Corresponding author: rabab.elamawi@yahoo.com \\ 2 Microbiology Department, College of Science, PO Box 22452, King Saud University, Soudi Arabia,
}

\begin{abstract}
Silver nanoparticles (AgNPs) was evaluated for its possible effects on the incidence of seed rot disease of Faba bean, Tomato and Barley caused by the seed and soil borne fungus Fusarium oxysporium. The Silver nanoparticles were biosynthesized by the fungus Trichoderma longibrachiatum and characterized by UVVisible (UV-Vis) spectroscopy, Transmission Electron Microscope (TEM) and Dynamic Light Scattering (DLS) (Raid, 2013). Silver nanoparticles characterized as spherical shape, almost monodispersed at size of $1-20 \mathrm{~nm}$. A preliminary study also performed in order to find out its suspected toxic effects, using different concentrations of Silver nanoparticles solutions on germination, vigour index and on the Fusarium oxysporium infection on the target crops. Silver nitrate solution or water treatment was used as positive and negative control respectively. Healthy and infected seeds were soaked in three different concentrations of Silver nanoparticles $(0.5,0.25$ and $0.12 \mathrm{mM})$. At the higher concentration, silver nanoparticles alone or in combination with Fusarium spores showed adverse effect on seed germination and vigour index. The lower concentration of silver nanoparticles improved the seed germination percentage and vigour index, in addition to reduce the disease incidence (seed rot disease) caused by Fusarium oxysporium. The higher concentration of Silver nanoparticles $0.5 \mathrm{mM}$ showed a slightly effects on seed germination percentage and vigour index in tomato seedlings. Silver nanoparticles at concentration of $0.12 \mathrm{mM}$ were less toxic to the tomato, faba bean and barley seedlings. It also reduced the disease incidence. Therefore, it is recommended to consider Silver nanoparticles in further studies for possible controlling of seed-borne pathogens putting in mind its possible accumulation in the crop products and the consecutive in food chain.

Keywords: Bio-synthesized silver nanoparticles, Trichoderma longibrachiatum, seed borne diseases and Fusarium oxysporium
\end{abstract}

\section{INTRODUCTION}

Fusarium oxysporum Schlecht. is a common soil fungus found in the rhizosphere vicinity of many plant species. Most $F$. oxysporum strains lives as saprophyte on organic substrates. However, some strains cause root rots and wilt diseases.Other $F$. oxysporum strains are effectively used as biocontrol agents. F. oxysporum is a very complex group, divided into Formae specials and physiological races depending on their pathogenicity towards particular plant species or cultivars (Armstrong \& Armstrong 1981). $F$. oxysporum produces chlamydospores, macroconidia and microconidia. 
Currently, the treatment of seeds using chemical fungicides before planting is the common used method to protect tomato and other plants from $F$. oxysporum infection. The application of chemical fungicides show divers effects on other living organisms including the useful soil microorganisms (Khalifa et al., 1995; Lewis et al., 1996). The alternative methods of pest control can play roles in management systems (Sutton, 1996).

Positive or negative effects of nanoparticles on higher plants were presented by several reports. Nano- $\mathrm{SiO}_{2}$ and nano- $\mathrm{TiO}_{2}$ lead to an increase in nitrate reducatase in Glycine max, it also enhances the ability to absorb and utilize water, stimulate the antioxidant effects and accelerate the germination and growth (Lu et al., 2002). Due to its variable shapes and sizes, it is difficult to predict their effects and mode of action in the environment (Holsapple et al., 2005). Alumina nanoparticles displayed inhibitions to root elongations of corn, cucumber, soybean, cabbage and carrot (Yang and Watts,2005). ZnO nanoparticles also inhibit root elongations of ryegrass, radish and rape (Lin and Xing, 2007).

The adverse effects of silver nanoparticles were studied on seed germinations, root and shoot growth on three plant species (Oryza sativa, Vigna radiata and Brassica campestris) when seeds were soaked in different concentrations of nanoparticles. In additions, $\mathrm{AgNPs}$ and $\mathrm{AgNO}_{3}$ significantly inhibited root growth of Eutrochium fistulosum and four Carex spp (Mazumdar and Ahmed, 2011). Silver nanoparticles were synthesized by chemical reduction methods (Yin et al., 2012).

Silver nanoparticles were applied for the control of microorganisms and the prevention of deleterious infections. Studies reveal that antimicrobial activity of the silver nanoparticles is due to their positive charge that qualifies them in reacting with the negatively charged proteins on the cell membranes and thus contributing to their antimicrobial activities (Hamouda et al., 2000 and Dragieva et al., 1999). The antifungal effects of silver nanoparticles were measured against eighteen plant pathogenic fungi including genera of Alternaria, Botrytis, Cladosporium, Corynespora, Cylindrocarpon, Fusarium, Pythium, Stemphylium (Kim et al. 2012). The antifungal activity of the biosynthesized nanoparticles from olive seed extract had been tested against different fungal plant pathogens viz: Aspergillus niger, Aspergillus falvus, Alternaria macrospora, Rhizoctonia bataticola and Sclerotium rolfsii using agar diffusion method (Khadriet al., 2013). The objectives of this research was carried out to evaluate the antimicrobial effects of bio-synthesized silver nanoparticles by Trichoderma longibrachiatum for controlling seed-borne pathogen (Fusarium oxysporum) which attack on tomato, faba bean and barley.

\section{MATERIAL AND METHODS}

Silver nanoparticles: $T$. longibrachiatum was isolated from cucumber leaves in Riyadh, Saudi Arabia and propagated according to Raida, 2013 methods. The silver nanoparticles were produced by $T$. longibrachiatum and characterized by different techniques including Ultraviolet-Visible 
spectroscopy, Fourier-Transformed-InfraRed spectroscopy, Transmission Electron Microscopy and Dynamic Light Scattering (Raida, 2013). These techniques provide information about the formation, size and morphology of the particles, capping proteins and stability.

Fungal isolation and pathogenicity test: $F$. oxysporum Schlecht. isolated from tomato fields around Riyadh city, Saudi Arabia, grown on PDA medium and incubated at $28^{\circ} \mathrm{C}$ for 7 days. Under sterile conditions, spores were harvested. Microconidia were separated from the mycelium by filtration the conidia suspension through three layers of filter papers. Microconidia suspension was concentrated by centrifugation at $4000 \mathrm{rpm}$ for $10 \mathrm{~min}$ and adjusted to $1.0 \times 10^{7}$ microconidia/ml. Virulence analysis of the $F$. oxysporum isolate was carried out on faba bean, tomato and barley seeds.

Effect of silver nanoparticles on colony formation of Fusarium oxysporum: $500 \mu \mathrm{l}$ of the conidial suspension were mixed with serial concentrations of silver particles and adjusted to a final volume of one $\mathrm{ml}$. Microconidial suspension was also prepared with sterile deionized water as control or mixed with the $1 \mathrm{mM} \mathrm{AgNO}_{3}$ solution which used as raw materials during nanoparticle synthesis. Treated conidia suspensions were incubated for $24 \mathrm{~h}$ at $28^{\circ} \mathrm{C}$ in an orbital shaker (120 rpm). $25-\mu$ l aliquot of the spore suspension of each treatment was spreaded on PDA medium. Three PDA plates for each treatment were used as replicate. The number of colonies formed on plates was counted after one and two days. The average number of colonies from silver-treated spore suspensions were compared with the number the $\mathrm{AgNO}_{3}$ solution and with the water control as percent colony formation.

Effects of silver nanoparticles on seed germination and inhibition of Fusarium oxysporum infection: Fifty seeds from each of faba bean, tomato or barley were subjected to standard blotter method in which the seeds were incubated according to the standard procedures of ISTA (ISTA, 1996). Seeds were surface sterilized in $5 \%$ sodium hypochlorite solution for 3 min and washed in three successive changes of sterile distilled water and left for air drying. Seeds were transferred onto filter paper in Petri dishes (10 seed per dish), soaked in different concentrations of AgNPs (0.5, 0.25 and $0.12 \mathrm{mM}$ ) alone or with Spore suspension at concentration 1.0 $\times 10^{7}$ microconidia/ml, $1 \mathrm{mM} \mathrm{AgNO}_{3}$ solution or fungal spores (positive control) or Sterile distilled water (negative control). After ten days of incubation period, the plates were examined for germination percentage, root length and shoot length. The infected seeds were also counted. Barley seedling was examined after 7 days for germination and growth rate. Germinated seed was considered when the radicle or plumule emerged from the seed coat.

Vigour Index was calculated by using the formula of Abdul Baki and Anderson (1973) as shown below:

Vigour Index $(\mathrm{VI})=($ Mean shoot length + mean root length $) \times$ Germination (\%).

Statistical analysis: Differences between treatments for the different measured variables were tested using one-way analysis of variance (ANOVA) with used Statistical Package for Social Sciences (SPSS), followed 
by Tukey's HSD post-hoc test when significant differences were found $(p=<$ 0.05). $P$ values lower than 0.05 were considered significant

\section{RESULTS AND DISCUSSION}

Silver nanoparticles activity against Fusarium oxysporum in vitro: Silver nanoparticles with size $1-20 \mathrm{~nm}$ at a concentration of $0.5 \mathrm{mM}$ was effective against Fusarium oxysporum and displayed $68.2 \%$ inhibition of colony formation comparing to the negative control (water) (Fig. 1) and (Table 1). Statistical analysis revealed a significant effect to the use of AgNPs and $\mathrm{AgNO}_{3}$ compared with the control treatment. The $\mathrm{P}$ value shows 0.047 that they have significant effect so; the nanoparticles strongly inhibited the fungal growth.

Silvers nanoparticles possess different properties, which might come from morphological, structural and physiological changes (Nel et al., 2003). Silver nanoparticles are highly reactive as they generate $\mathrm{Ag}^{+}$ions while metallic silver is relatively unreactive (Morones et al., 2005). Also, the nanoparticles efficiently penetrate into microbial cell, which implies lower concentrations of nano-sized silvers sufficient for microbial control. A previous study indicates that silver nanoparticles disrupt transport systems including ion efflux (Morones et al., 2005). Also, silver ions are known to produce active oxygen species (ROS) via their reaction with oxygen, causing damage to cells proteins, lipids, and nucleic acids (Storz \& Imlay, 1999 and Hwang et al., 2008).

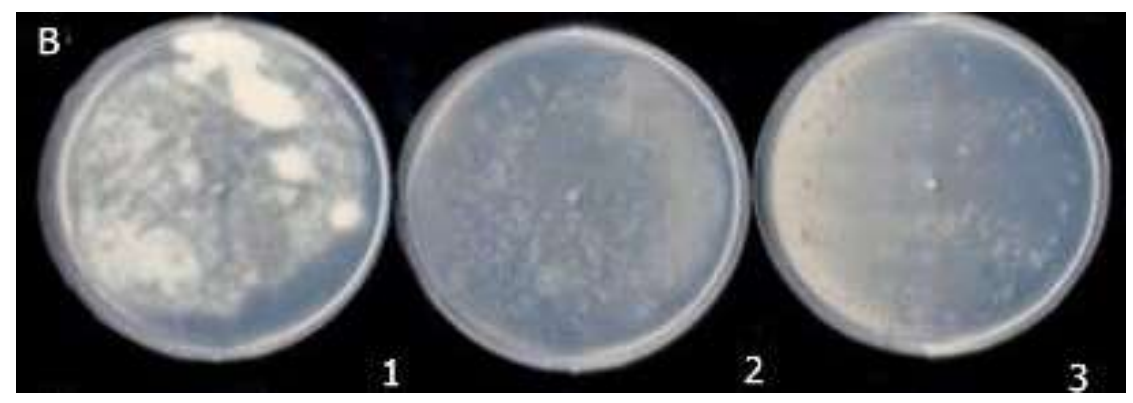

Figure-1: Antifungal activity of biosynthesis silver nanoparticles against colonies formation of Fusarium oxysporum. (1) Control, (2) $\mathrm{AgNO}_{3},(3)$ Silver NPs mixed with $F$. oxysporum spores for $24 \mathrm{~h}$.

Table 1: Effect of AgNPs synthesized by Trichoderma longibrachaitum on colonies formation of $F$. oxysporum

\begin{tabular}{|c|c|c|c|c|}
\hline \multirow{2}{*}{ Fungus } & \multicolumn{4}{|c|}{ Number of formed-colonies $/ \mathbf{c m}^{\mathbf{2}}$} \\
\cline { 2 - 5 } & Control & $\mathbf{A g N O}_{\mathbf{3}}$ & $\mathbf{A g - N P s}$ & $\mathbf{P}$ value $<\mathbf{0 . 0 5}$ \\
\hline Fusarium oxysporum & 13.92 & 5.92 & 4.42 & 0.047 \\
\hline$\%$ & & 57.5 & 68.2 & \\
\hline
\end{tabular}


Effects of silver nanoparticles on Fusarium oxysporum infection, germination and viguor index: The disease incidence of $F$. oxysporum was shown on tomato, faba bean and barley seeds at percentage of 100, 80 and $50 \%$ respectively, (Table 2, 3 and 4 ).

Different concentrations of silver nanoparticles $(0.5,0.25$ and 0.12 $\mathrm{mM}$ ) alone or incombination with spore suspension of $F$. oxysporum, $1 \mathrm{mM}$ silver nitrate, compared with spore suspension of $F$. oxysporum or sterilize distilled water were used to determine seed germinations(\%), disease incidence $(\%)$, root length $(\mathrm{cm})$, shoot length $(\mathrm{cm})$ and vigour index on three different crops viz: fababean, tomato and barley. Data illustrated in Table (2) and Fig (2) indicate that the seed germination of tomato plant was not affected by silver nanoparticles concentration but vigour index was affected at the highest concentration of AgNPs. Whereas, negative control (water) showed highest vigour index value 870 but the positive control treatment with $\mathrm{AgNO}_{3}$ reduced seed germination to $70 \%$ compared with $100 \%$ of the negative control (water) while the low value of vigour index was 30.1. Treatment with Fusarium infection reduced the germination to $10 \%$ and vigour index to 18.2. Correspondingly, the disease incidence (rot seed \%) of infected tomato with Fusarium was $100 \%$. The formulated treatment 'of AgNPs at different concentrations and Fusarium suspension showed a significant inhibition in diseases incidence (rot seed) to present $5 \%$ infection only. Germination percentage of tomato seeds was not affected by the treatments, but vigour index was affected by the mixture of AgNPs at $0.5 \mathrm{mM}$ with Fusarium spores. Tomato roots were sensitive to all silver nanoparticle treatments. The $0.5 \mathrm{mM} \mathrm{AgNPs}$ and $1 \mathrm{mM} \mathrm{AgNO}_{3}$ had noticeable effected on the shoot length. $\mathrm{AgNO}_{3}$ had stronger inhibitory effect than AgNPs on tomato shoot length. Negative effects in root and shoot length was observed as brown color on some parts of roots. Tomato seeds were affected by a number of diseases, among them; wilt disease caused by F. oxysporum f. $s p$. Lycopersici (Suarez-Estrella et al., 2007 and Kim and Kim 2008). A new approach in crop protection is to reduce the disease damage level using silver nanoparticles. Data presented here suggest silver nanoparticles as a possible approach for controlling seed-borne pathogens. 


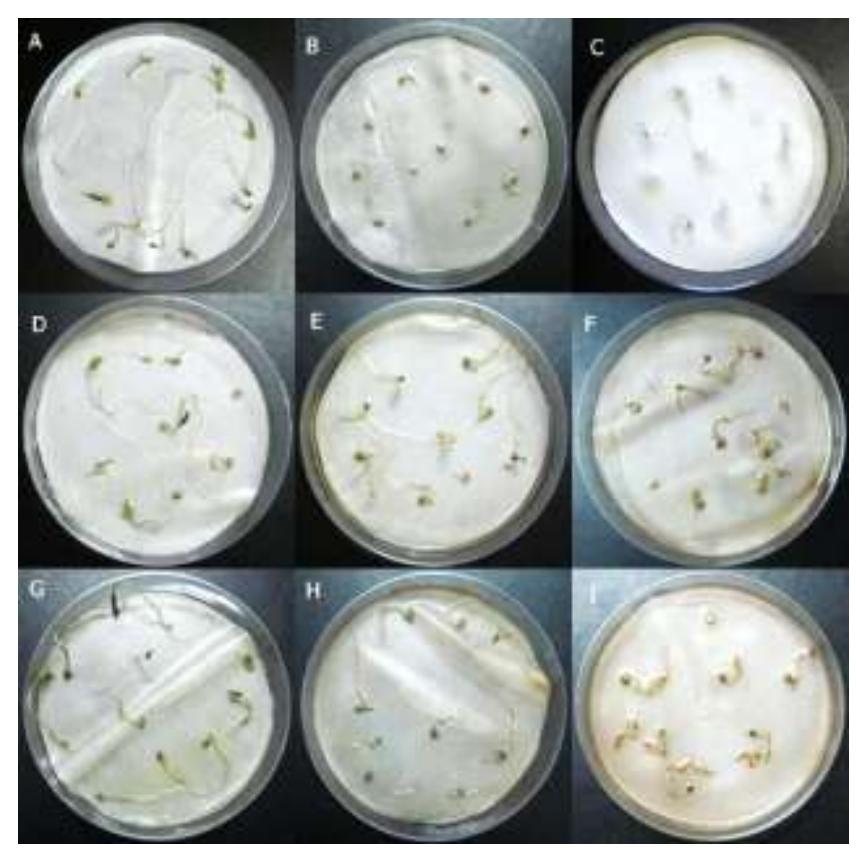

Figure-2: Effect of AgNPs on tomato seed germination after 10 days. A; Control (water), B; $1 \mathrm{mM} \mathrm{AgNO}$, C; Fusarium oxysporum spore suspension (SS), AgNPs concentrations, D; $0.12 \mathrm{mM}, \mathrm{E} ; 0.25 \mathrm{mM}$, F; 0.5mM, G; SS + 0.12mM AgNPs, (H) SS + 0.25mM AgNPs, and (I) $\mathrm{SS}+0.5 \mathrm{mM}$ AgNPs.

Table 2:The effect of AgNPs on germination of tomato seeds, vigour index and Fusarium oxysporum infection

\begin{tabular}{|c|c|c|c|c|c|c|c|}
\hline Treatments & 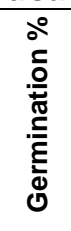 & 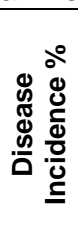 & 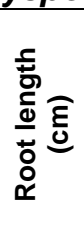 & $\begin{array}{l}\qquad \\
0 \\
0 \\
\text { vi } \\
11 \\
0 \\
\frac{0}{\pi} \\
2 \\
0\end{array}$ & 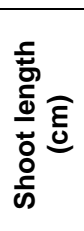 & $\begin{array}{l}\qquad 0 \\
0 \\
0 \\
\text { vi } \\
11 \\
0 \\
\frac{0}{\pi} \\
D \\
0\end{array}$ & 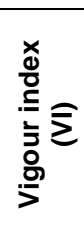 \\
\hline Control (water ) & 100 & - & 6.8 & 0.000 & 1.9 & 0.000 & 870 \\
\hline $\mathrm{AgNO}_{3} 1 \mathrm{mM}$ & 70 & - & 0.43 & $0.000^{\star \star}$ & 0 & $0.000^{* *}$ & 30.1 \\
\hline AgNPs $0.12 \mathrm{mM}$ & 90 & - & 4.6 & 0.078 & 0.9 & 0.210 & 495 \\
\hline AgNPs $0.25 \mathrm{mM}$ & 100 & - & 3.25 & $0.000^{\star *}$ & 1.27 & 0.787 & 452 \\
\hline AgNPs $0.5 \mathrm{mM}$ & 90 & - & 0.83 & $0.000^{\star \star}$ & 0.47 & $0.046^{*}$ & 117 \\
\hline AgNPs $0.12 \mathrm{mM}+\mathrm{SS}$ & 100 & 5 & 2.30 & $0.000^{* *}$ & 2.33 & 0.971 & 463 \\
\hline AgNPs $0.25 \mathrm{mM}+\mathrm{SS}$ & 100 & 5 & 1.75 & $0.000^{* \star}$ & 0.67 & $0.051^{*}$ & 242 \\
\hline AgNPs $0.5 \mathrm{mM}+\mathrm{SS}$ & 90 & 5 & 1.75 & $0.000^{\star \star}$ & 0.1 & $0.000^{\star \star}$ & 166.5 \\
\hline F. oxysporum & 10 & 100 & 1.6 & $0.000^{* *}$ & 0.22 & $0.000^{* *}$ & 18.2 \\
\hline
\end{tabular}


In case of faba bean, concentrations of AgNPs at $0.12 \mathrm{mM}$ and $0.25 \mathrm{mM}$ alone or incombination with the Fusarium spore suspension did not show any significant differences in seed germination percentage, diseases incidence (rot seeds), and vigour index compared the control or $1 \mathrm{mM} \mathrm{AgNO}_{3}$. AgNPS at concentration of $0.25 \mathrm{mM}$ significantly reduced the shoot length Fig. (3) and (Table 3). The concentration of $0.5 \mathrm{mM}$ of AgNPs alone or incombination with Fusarium spore suspension significantly reduced germination percentage by 60 and $70 \%$, and vigour index value by 72 and 97.3, respectively compared with the control (water), $1 \mathrm{mM} \mathrm{AgNO3}$ or Fusarium infection. Whereas, the $P$ value less than 0.05 was considered significant. Furthermore, it was observed that the roots became colored with brown dark regions as result to AgNPs treatments. Treatment with seed borne pathogen Fusarium caused a reduction in faba bean seed germination as it reached $20 \%$. The disease incidence of Fusarium infection recorded as rotted-seeds was $50 \%$. But, incidence of Fusarium infection was reduced when the faba bean seeds treated with any of AgNPs concentration to record $5 \%$. Faba bean seeds treated with low concentration of AgNPs showed a great impact on germination and reduced the disease incidence.

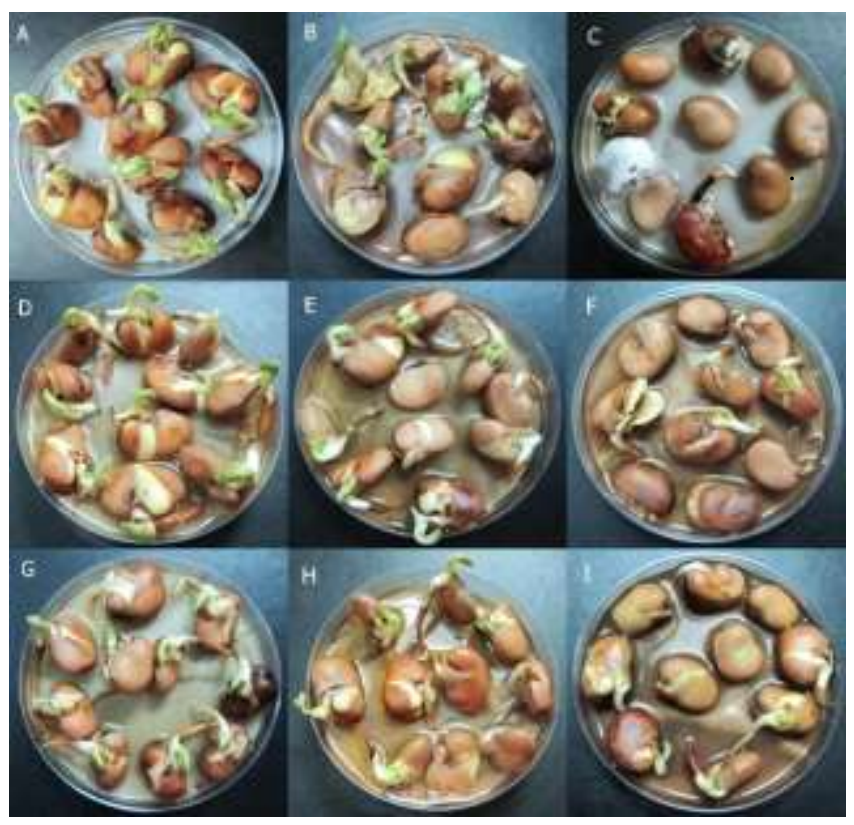

Figure 3: Effect of AgNPs on faba bean seed germination after 10 days. A; Control (water), $\mathrm{B} ; 1 \mathrm{mM} \mathrm{AgNO}_{3}, \mathrm{C}$; Fusarium oxysporum spore suspension (SS), AgNPs concentrations, D; $0.12 \mathrm{mM}$, E; 0.25mM, F; 0.5mM, G; SS + 0.12mM AgNPs, (H) SS $+0.25 \mathrm{mM}$ AgNPs, and (I) SS + 0.5mM AgNPs 
Table 3: The effect of AgNPs on germination of faba bean seeds, vigour index and Fusarium oxysporum infection.

\begin{tabular}{|c|c|c|c|c|c|c|c|}
\hline Treatments & 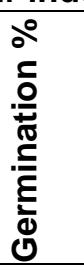 & 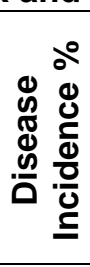 & 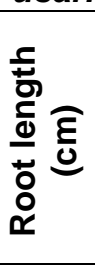 & 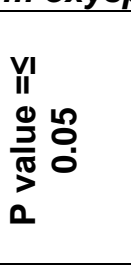 & 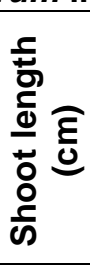 & $\begin{array}{l}\text { VI } \\
\text { II } \\
0 \\
\frac{0}{2} \\
\frac{0}{N} \\
\sum_{0} \\
0\end{array}$ & 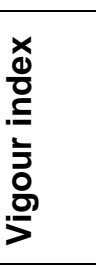 \\
\hline Control (water) & 100 & 0 & 2.67 & 0.000 & 1.52 & 0.000 & 419 \\
\hline $\mathrm{AgNO}_{3} 1 \mathrm{mM}$ & 90 & 0 & 2.6 & 1.000 & 0.82 & 0.258 & 307.8 \\
\hline AgNPs $0.12 \mathrm{mM}$ & 100 & 0 & 2.33 & 0.999 & 1.45 & 1.000 & 378 \\
\hline AgNPs $0.25 \mathrm{mM}$ & 100 & 0 & 2.2 & 0.992 & 0.35 & $0.001^{* *}$ & 255 \\
\hline AgNPs $0.5 \mathrm{mM}$ & 60 & 0 & 0.9 & $0.026^{*}$ & 0.3 & $0.000^{* *}$ & 72 \\
\hline AgNPs0.12mM+SS & 100 & 5 & 2.95 & 1.000 & 1 & 0.723 & 395 \\
\hline AgNPs0.25mM+SS & 90 & 5 & 2.03 & 0.966 & 0.67 & 0.063 & 243 \\
\hline AgNPs $0.5 \mathrm{mM}+\mathrm{SS}$ & 70 & 5 & 1.04 & $0.055^{\star}$ & 0.35 & $0.001^{* *}$ & 97.3 \\
\hline F. oxysporum & 20 & 50 & 0.15 & $0.000^{\star \star}$ & 0.2 & $0.000^{* *}$ & 7 \\
\hline
\end{tabular}

SS = F. oxysporum spores suspension; * mean difference is significant at the 0.05 level

In case of Barley seeds, Fig (4) and Table (4) illustrate that $0.5 \mathrm{mM}$ AgNPs alone or incombination with Fusarium spore suspension caused significant inhibition of seed germination by 70 and $60 \%$, respectively. While, vigour index value was also decreased to 167.3 and 177 , respectively compared to the control (water) which record 1450. Treatment with seed borne pathogen Fusarium caused a reduction in barley seed germination as it reached $60 \%$. The incidence of Fusarium infection recorded as rottedseeds was $80 \%$. But, the incidence of Fusarium infection reduced when the barley seeds treated any of the different AgNPs concentrations to record $5 \%$ only.

Germination percentage and vigour index were measured to determine the effects of $\mathrm{AgNPs}, \mathrm{AgNO}_{3}$, in the presence of Fusarium infection on faba bean, tomato, and barley. Consistent with our expectations, the AgNPs were toxic to seedling, and both vegetative growth and root elongation were inhibited at higher concentrations. This phenomenon was also reported in aquatic (Lemna minor) and terrestrial (Lolium multiflorum) plants, algae, fungi, vertebrates (zebra fish), invertebrates (Caenorhabditis elegans), reviewed by Levard et al., 2012. 


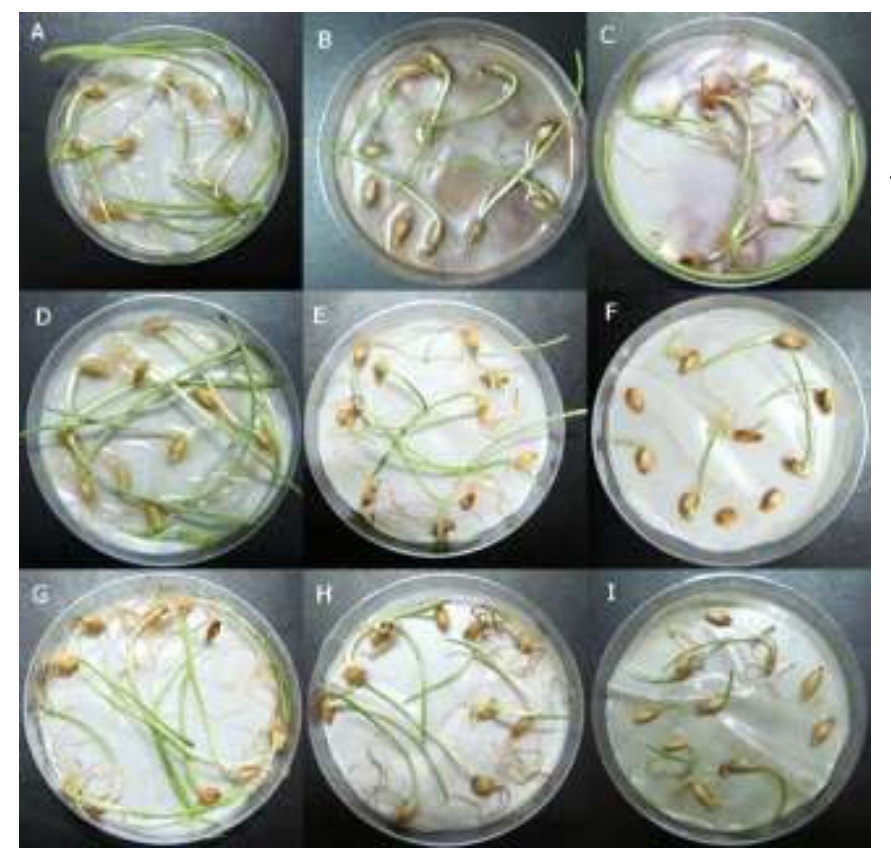

Figure 4: Effect of AgNPs on barley seed germination after 10 days. A; Control (water), B; $1 \mathrm{mM} \mathrm{AgNO} 3, \mathrm{C}$; Fusarium oxysporum spore suspension (SS).AgNPs concentrations, D; $0.12 \mathrm{mM}$, $\mathrm{E} ; 0.25 \mathrm{mM}$, F; 0.5mM, G; SS + 0.12mM AgNPs, (H) SS + $0.25 \mathrm{mM}$ AgNPs, and (I) SS + 0.5mM AgNPs

Table 4: Effect of AgNPs on the germination of barley seeds, vigour index and Fusarium oxysporum infection.

\begin{tabular}{|c|c|c|c|c|c|c|c|}
\hline Treatments & 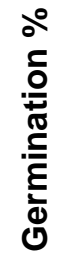 & 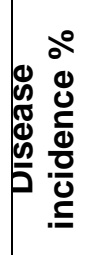 & 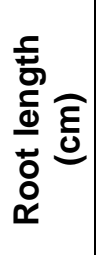 & 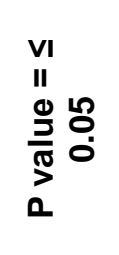 & 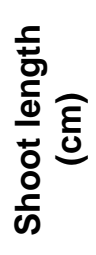 & 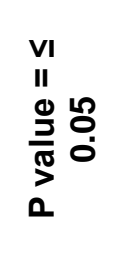 & 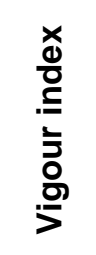 \\
\hline Control (water ) & 100 & - & 5.8 & 0.000 & 8.7 & 0.000 & 1450 \\
\hline $\mathrm{AgNO}_{3} 1 \mathrm{mM}$ & 70 & - & 3.25 & 0.360 & 0.33 & $0.000^{* *}$ & 250.6 \\
\hline AgNPs $0.12 \mathrm{mM}$ & 100 & - & 6.77 & 0.994 & 7.53 & 0.968 & 1430 \\
\hline AgNPs $0.25 \mathrm{mM}$ & 100 & - & 2.8 & 0.166 & 5.72 & 0.112 & 852 \\
\hline AgNPs $0.5 \mathrm{mM}$ & 70 & - & 0.23 & $0.000^{* \star}$ & 2.16 & $0.000^{* *}$ & 167.3 \\
\hline AgNPs0.12mM+SS & 100 & 5 & 6.79 & 0.366 & 7.17 & 1.000 & 1396 \\
\hline AgNPs $0.25 \mathrm{mM}+\mathrm{SS}$ & 90 & 5 & 3.37 & 0.427 & 4.91 & 0.013 & 745.2 \\
\hline AgNPs $0.5 \mathrm{mM}+\mathrm{SS}$ & 60 & 5 & 1.18 & $0.003^{\star \star}$ & 1.77 & $0.000^{* \star}$ & 177 \\
\hline F. oxysporum & 60 & 80 & 1.65 & $0.010^{\star}$ & 2.77 & $0.000^{* *}$ & 265.2 \\
\hline
\end{tabular}


The current study showed that the inhibitory effect of $\mathrm{AgNO}_{3}$ on seedling growth is higher than that of AgNPs. This results is different from the finding of Yin et al., (2011) who illustrated that AgNPs has stronger inhibitory effect on Lolium multiflorum growth than $\mathrm{AgNO}_{3}$. Results also showed that tomato, faba beans and barley plants were differ in their tolerant to AgNPs and $\mathrm{AgNO}_{3}$. AgNPs' toxicity on seedling growth under normal growth conditions was partially consistent in the pure culture experiments. Therefore, the increase in the release of AgNPs into the environment may show adverse effects on wetland plants.

AgNPs reduced the incidence of $F$. oxysporum infection as a seed borne pathogen in all used concentrations and on seeds of plant species viz: tomato, faba bean and barley with no significant differences in disease incidence as it recorded $5 \%$ only. Silver ions produce active oxygen species (ROS) via their reaction with oxygen, causing damage to cells proteins, lipids, and nucleic acids (Storz and Imlay, 1999; Wang et al., 2008). F. oxysporum can live in the soil for long period of time; therefore the rotational cropping is not a useful control method. The fungus also spreads through infected dead plant materials and that makes cleaning up at the end of the season is important practice. However, the control methods of $F$. oxysporum as a damping-off pathogen could be carried out by planting resistant varieties, and using chemical reagent as antifungal (Khalifa et al., 1995; Lewis et al., 1996 and Sutton, 1996). However, the study suggests the possible use of silver nanoparticles as a new approach for the eradication of phytopathogens even though there are some restrictions of using the nanoparticles in horticulture. These may involve the evaluation of phytotoxicity and antimicrobial effects in hosts, and development of delivery systems of silver nanoparticles into host tissues colonized by phytopathogens.

\section{CONCLUSION}

A high concentration of AgNPs showed a negative effect on faba bean and barley seedlings, whereas the germination percentage, vigour index were significantly decreased. The low concentration of AgNPs improved the germination percentage; vigour index in addition to reducing the disease incidence (rotted seeds) resulted from the inoculation with Fusarium spores. On the other hand, a high concentration of AgNPs did not show a significant effect on tomato seedling whereas the germination percentage, vigour index were slightly decreased. Silver nanoparticles, at a concentration $0.12 \mathrm{mM}$ were less toxic to the seedlings of tomato, faba beans and barley; also it reduced the growth of Fusarium infection. These preliminary studies propose the use silver particles for controling seed-borne pathogens. Further studies are recommended to study the divers effect on nanoparticles used in the formulated pesticides on the environment as well as their passing through the food chain and subsequently their possible accumulation in the human bodies. 


\section{REFERENCES}

Abdul Baki A.A. and Anderson J.D., (1973). Vigor determination in soybean seed by multiple criteria. Crop Science, 13: 630-633.

Armstrong G.M. and Armstrong J.K., (1981). Formae specials and races of Fusarium oxysporum causing wilt diseases. In: Nelson PE, Toussoun TA, Cook RJ, editors. Fusarium: Diseases, biology and taxonomy. University Park, USA: The Pennsylvania State University Press. 392399.

Dragieva I. Stoeva P. Stoimenov E. Pavlikianov and Klabunde K., (1999). Complex Formation in Solutions for Chemical Synthesis of Nanoscaled Particles Prepared by Borohydride Reduction Process, Nanostructured Materials. 12, No. 1: 267-270.

Hamouda T.A. Myc B. Donovan A. Shih J. D. Reuter and Baker J. R., (2000). A Novel Surfactant Nanoemulsion with a Unique Non-Irritant Topical Antimicrobial Activity against Bacteria, Enveloped Viruses and Fungi, Microbiological Research, Vol. 156, No. 1: 1-7.

Holsapple M. Farland. W. Landry T. Monteiro-Riviere N. Carter J., Walker N. and Thomas K. (2005). Research strategies for safety evaluation of nanomaterials, Part II: Toxicological and safety evaluation of nanomaterial. Current challenges and data needs. Toxicological Science.88:412-419.

Hwang E. Lee J. Chae Y. Kim Y. Kim B. Sang B. and Gu M. (2008). Analysis of the toxic mode of action of silver nanoparticles using stress-specific bioluminescent bacteria. Small 4,746-750.

ISTA, 1996. International Rules of Seed Testing Association. In. Proc. Int. Seed Test. Assoc., pp: 19-41.

Khadri H. Alzohairy M. Janardhan A. Kumar A. Narasimha G., (2013). Green Synthesis of Silver Nanoparticles with High Fungicidal Activity from Olive Seed Extract. Advances in Nanoparticles, 2, 241-246.

Khalifa, E. El-Shenawy, Z. and Awad, H. M., (1995). Biological control of damping-off and root-rot of sugar beet. Egypt.J.Phytopathol. 23, 39-51.

Kim J. and Kim J., (2008). Inhibitory Effect of Algal Extracts on Mycelial Growth of the Tomato-Wilt Pathogen, Fusarium oxysporum $f$. $s p$. Lycopersici. Mycobiology 36 (4), 242-248.

Kim S. Jung J. Lamsal K. Min J. and Lee Y. (2012). Antifungal Effects of Silver Nanoparticles against Various Plants Pathogenic Fungi. Mycobiology, 40 (1), 53-58.

Levard C. Hotze E. Lowry G. V.and Brown G., (2012). Environmental transformations of silver nanoparticles: impact on stability and toxicity. Environmental Science and Technology, 46 (13), 6900 -6914.

Lewis J. A. Lumsden R. D. and Locke J. C., (1996). Biocontrol of damping-off diseases caused by Rhizoctonia solani and Pythium ultimum with alginate prills of Gliocladium virens, Trichoderma hamatum and various food bases. Biocontrol Science Technology. 6, 163-173. 
Lin D. and Xing B.S., (2007). Phytotoxicity of nanoparticles: inhibitions of seed germinations and root elongations. Environmental Pollution, 150, 243-250.

Lu C.M. Zhang C.Y. Wen J.Q. Wu G.R. and Tao M.X., (2002). Research of the effect of nanometer materials on germination and growth enhancement of Glycine max and its mechanism. Soybean Science: 168-172.

Mazumdar H. and Ahmed G.U., (2011). Phytotoxicity effect of Silver nanoparticles on Oryza sative. International Journal of Chem Tech Research, 3, 1494-15.

Morones J.R. Elechiguerra J.L. Camacho A. Holt K. Kouri J.B. Ramirez J.T.and Yacaman M.J. (2005). The bactericidal effect of silver nanoparticles. Nanotechnology.16: 2346-2353.

Nel A. Xia T. Madler L. and Li N., (2003). Toxic potential of materials at the nanolevel. Science 311, 622-627.

Raida Al-Harbi, (2013) Biosynthesis and characterization of Silver nanoparticles by using fungi and their applications. Ph.D. Thesis.

Storz G. and Imlay J. A., (1999). Oxidative stress. Current Opinion in Microbiology2, 188-194.

Sutton T. B., (1996). Changing options for the control of deciduous fruit tree diseases. Annual Review of Phytopathology.34,527-547.

Suarez-Estrella F. Vargas-Garcia C. Lopez M. Capel C. and Moreno J., (2007). Antagonistic activity of bacteria and fungi from horticultural compost against Fusarium oxysporum $f$. $s p$ melonis. Crop Protection, 26:46-53.

Yang L. and Watts D.J., (2005). Particle surface characteristics may play an important role in phytotoxicity of alumina nanoparticles. Toxicology Letters. 158:122-132.

Yin L. Cheng Y. Espinasse, B. P. Colman B. Auffan M. Wiesner M. Rose J. Liu J. and S. Bernhardt E., (2011). More than the lons: The Effects of Silver Nanoparticles on Lolium multiflorum. Environmental Science. Technology 45, 2360-2367.

Yin L. Colman B.P. Mcgill B.M. Wright, J.P. and Bernhardt, E.S., (2012). Effects of Silver Nanoparticle Exposure on Germination and Early Growth of Eleven Wetland Plants, PLos one, 7(10):1. 


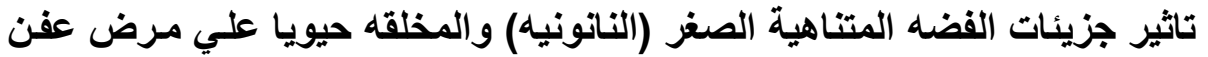

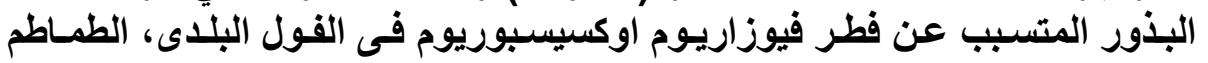
والثعير رباب ممدوح أحمد العماوي 1 و رائدة بنت إبراهيم بن عبدالله الحربي 2

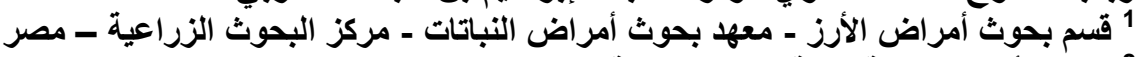
2 قسم الأحياء الدقيقة. كلية العلوم- جامعة الملك سعود التبد

أجرى تقييم للتأثير العكسى لسمية جزيئات الفضة النانونية بإستخدام إختبار إنبات البذور

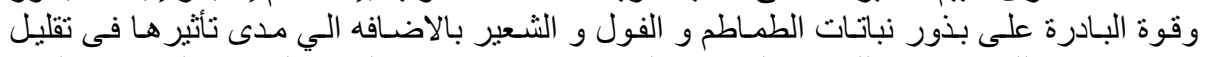

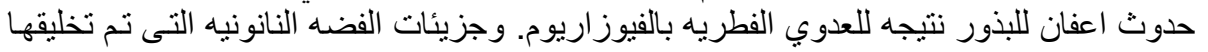

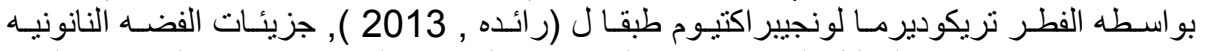

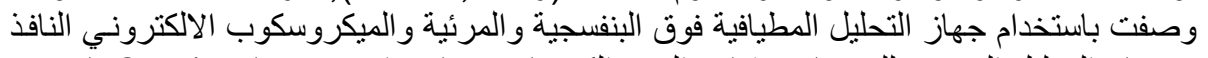

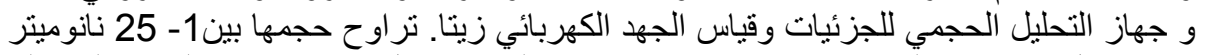

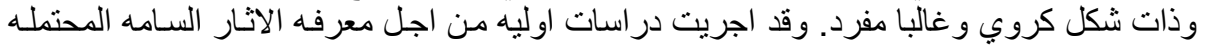

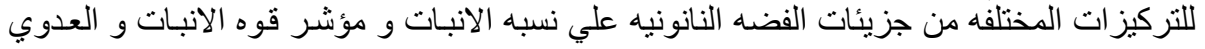

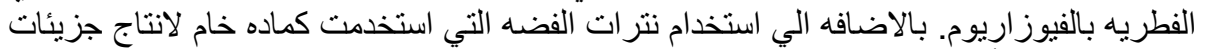

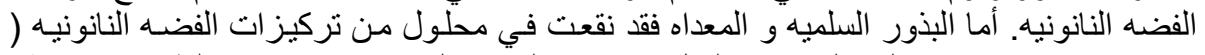

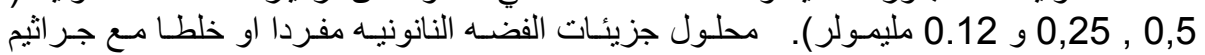

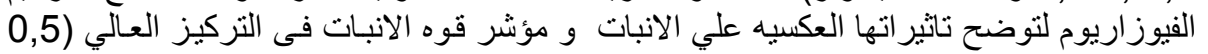

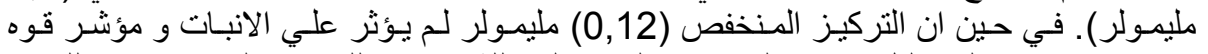

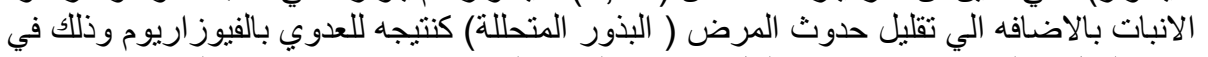

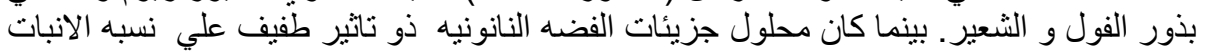

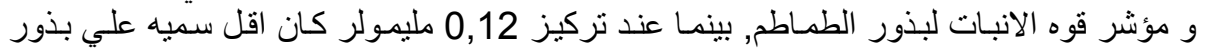

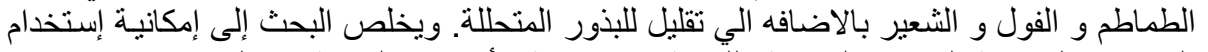

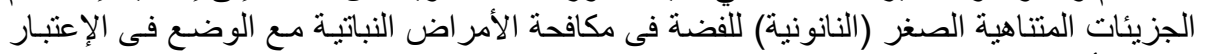

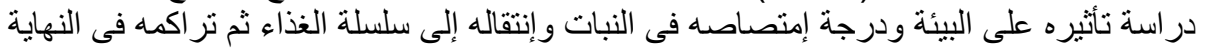
فى جسم الإنسان وما قد ينجم عن ذلك من آثار سلبية.

كلية الزراعة - جامعة المنصورة

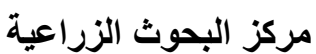

قام بتحكيم البحث

أ.د / محمد عبد الرحمن الوكيل

أ.د / محمد رشدى سحلى "ي 